ECONOMICS

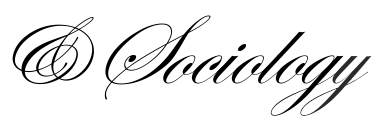

Musova, Z., Musa, H., \& Matiova, V. (2021). Environmentally responsible behaviour of consumers: Evidence from Slovakia. Economics and Sociology, 14(1), 178-198. doi:10.14254/2071-789X.2021/14-1/12

\title{
ENVIRONMENTALLY RESPONSIBLE BEHAVIOUR OF CONSUMERS: EVIDENCE FROM SLOVAKIA
}

\section{Zdenka Musova}

Matej Bel University in Banske Bystrica, Faculty of Economics, Banska Bystrica, Slovakia E-mail: zdenka.musova@umb.sk ORCID 0000-0002-1067-8291

\section{Hussam Musa}

Matej Bel University in Banske a Bystrica, Faculty of Economics, Banska Bystrica, Slovakia E-mail: bussam.musa@umb.sk ORCID 0000-0002-4492-8770

\section{Veronika Matiova \\ Matej Bel University in Banske a Bystrica, Faculty of Economics, Banska Bystrica, Slovakia E-mail: veronika.matiova@umb.sk.}

Received: January, 2020 1st Revision: July, 2020 Accepted: January, 2021

DOI: $10.14254 / 2071-$ 789X.2021/14-1/12

JEL Classification:M14, M30, M31
ABSTRACT. Consumers give special importance to higher environmental responsibility which is expected to improve the environment quality. The aim of this paper is to present the selected results of the examination focused on Slovak consumers' environmentally responsible behaviour. The frequency of implementing responsible activities within the circular economy principles was investigated. The environmentally responsible consumer behaviour in the context of the selected demographic characteristics of consumers and approaches to environmental issues were also studied. The paper contains the results aimed at consumers' perception and knowledge of eco-labels and the impact on purchasing behaviour too. Secondary data analysis is supplemented by the results of the primary research as of November and December 2018, which was conducted via an online questionnaire on the sample of 434 respondents from Slovakia. The obtained data were evaluated by selected statistical methods (Chi-square test, Spearman's correlation coefficient, ordinal regression, factor analysis). Consumers pay an adequate amount of attention to implementation of responsible activities, and this suggests positive changes in consumers' perception and approaches to environmental issues. Testing confirmed that statistically significant variables influencing environmentally responsible behaviour of consumers are age, gender, income, number of household members, environmental attitudes and knowledge of eco-labels.

Keywords: environmental responsibility, consumer, circular economy principles, environmental purchasing, eco-labels, Slovakia 


\section{Introduction}

In the context of current trends, the situation in the environment is increasingly deteriorating. With growth of human capabilities in recent centuries, the environmental equilibrium was disrupted (Esmaeilpour \& Bahmiary, 2017). The environmental issue has emerged as one of the critical societal priorities (Howard-Grenville et al., 2014; Potocan et al., 2016) and as a new development strategy of organizations (Pham et al., 2019). Environmental problems are deepening, and in many cases, are becoming global. According to Chion et al. (2011), growing environmental problems caused by industrialization have increased the environmental concerns of customers, communities and governments. Solving this negative situation is becoming a challenge not only for governments of individual countries, but also for market subjects - businesses and consumers - thus, all must be looking for solutions.

The period of growing negative climate and environmental changes creates a significant area for more environmentally responsible behaviour of market subjects. Environmentally responsible businesses implement environment-friendly strategies with the aim to contribute at least partially to solving the problems in the environment. Many consumers act responsibly towards the environment, their environmental awareness grows, and they emphasize their environmental requirements while performing purchases. Environmentally responsible behaviour of consumers is a reaction to socially responsible marketing, which highlights the need to pay attention to social, ethical, legal, and environmental aspects of business activities in relation to their stakeholders (Musova et al., 2018).

Braam et al. (2018) stated that more and more organizations (including NGOs) are working in cooperation with state institutions on the transition of national economies on the new economic model - circular economy (CE). According to Hankammer et al. (2019), consumers play a significant and active role in the success of this CE model implementation. It is not only about seeking environmentally friendly products, it is also about being a part of a closed loop, about cooperating with other market players, buying products from companies that are taking responsibility for their business, separating and recycling waste in accordance with the principles of circular economy.

According to Special Eurobarometer 468 (EC, 2017), large majority of the Europeans believe they can play a role in protecting the environment More than eight out of ten Europeans (87\%) agree that they can play a role; of these, $45 \%$ 'totally agree' with the statement, and $42 \%$ 'tend to agree'. Only $11 \%$ of the surveyed disagree with this. These findings have been very consistent over time since the 2007 survey, with the agreement ranging between $85 \%$ and $87 \%$ over the ten-year period. The respondents in the Netherlands (97\%), Sweden and Ireland (both 96\%) are the most likely to agree that they can play a role in protecting the environment. The lowest levels of agreement can be seen in Bulgaria (73\%), Latvia (76\%) and Estonia (77\%).

The number of studies on environmentally responsible consumer behaviour during the past decade has increased and contributed to the research conducted on environmental attitudes and their effect on consumers' behaviour. This change in consumer behaviour has helped the beginning of the ,green revolution" meant to avoid further harm to the environment (Juwaheer et al., 2012). Thus, the issue of preserving our environment has caused consumers to reconsider their choice of products. For the protection of the environment, many consumers are ready to pay higher prices for products that comply with environmental standards (Newton et al., 2015). The impact of this is seen when companies and organizations are turning more towards environment-friendly products (Finisterra et al., 2009).

In this context, the paper focuses on the research of the selected aspects of environmentally responsible behaviour among consumers in Slovakia. Consumer behaviour while implementing selected environmentally responsible activities with regard to circular 
economy principles will be examined. Environmentally responsible behaviour of consumers and its correlation with the selected demographic characteristics and eco-labels knowledge will be investigated. Eco-label guarantees that the product affects the environment less than other products with comparable quality attributes since its development, throughout the production, up to its disposal after it has been consumed (Minarova et al., 2016).

The paper is organized as follows. After the introduction, the literature review is provided in Section 1. Section 2 illustrates the applied methodology through research design, sample size, data collection and data analysis. The paper presents and discusses the empirical results in Section 3. The Conclusion sums up the most important research outcomes and recommendations for future research.

\section{Literature review}

Environmentally responsible (pro-environmental) behaviour reflects behaviour that harms the environment as little as possible or even benefits it (Steg \& Vlek, 2009). Throughout the years, this behaviour and "green" consumption have been defined in different ways. For some people, "green" means an attitude. Environmentally responsible consumers see the deterioration of current conditions in environment as a global security problem. Others, who are less aware of environmental problems, believe that these problems will sort themselves out. Many studies are focused on consumer behaviour from the point of their environmental impacts and only certain stages of this behaviour are taken into account. Onel \& Mukherjee (2016) state, it is therefore very important to concentrate on broader context of consumer behaviour in various stages, on their impact on the environment, as well as their contribution to limiting environmental problems

In relation to environmental responsibility, the concept of sustainable consumption is increasingly emerging. The main idea is to give preference to environmental products in conjunction with the consumption of an adequate quantity of renewable natural resources and products. Pajtinkova Bartakova \& Gubiniova (2012) agree with the UN and OECD definition according to which sustainable consumption is the use of goods and services that respond to basic needs and bring a better quality of life, while minimising the use of natural resources, toxic materials and emissions of waste and pollutants over the life-cycle, so as not to jeopardise the needs of future generations.

The aim of adopting such a behaviour is either to manifest a positive influence or to reduce the negative impact on the environment. At an organizational/businesses level, it could mean the production of goods that are environmentally friendly. At the level of consumer behaviour, the definition highlights the way of reducing the negative influence of one person on the environment. Roman et al. (2015) clarify, that the awareness of green consumption has more of a social side, and the definition could be reformulated to reflect a more long-term focus on the well-being of the individual and the society through the reduction of the negative impact of a certain product.

Several studies (Paul \& Rana, 2012; Fraj \& Martinez, 2007) have shown, that the consumers belonging to the environmentally responsible segment are characterized by their self-fulfilment. These people always believe in self-improvement and take actions, which are challenging. They are interested in ecological lifestyle, are environmentally conscious, they carefully select and reject products and are volunteers in various events for environment protection. This segment take interest in socially responsible firms which are committed to environment protection and launch new "green" products.

The consumers in this segment when purchasing are interested in environmental products, not merely because of healthier option but it also hopes in sustaining the environment 
for future generation. Different researchers explored the various features which contributed to shape the nature of behaviour of environmental consumers. According to Mostafa (2007) the influence of consumer environmental knowledge, concern and attitude on gender differences in environmental purchase behaviour was confirmed. Environmental consumers are usually welleducated, young adult women, who have more money to spend.

Overall, environmental concern indicates the degree to which people are aware of problems regarding the environment and support efforts to solve them and or indicate the willingness to contribute personally to their solution (Dunlap \& Jones, 2002). This willingness is connected with a certain form of motivation. The motivation to be environmentally responsible is closely connected to consumers' personal commitment to environmental protection and their actions on an individual level to improve its quality. Consumers are aware of the adverse effects of the environment on human and other living beings and understand their individual responsibility to protect the environment (Gadenne et al., 2011). Environmental concerns, compassion and belief in the existence of environmental problems lead consumers to a more appropriate behaviour towards the environment (Kilborune \& Pickett, 2008) and these consumers start purchasing environmental products (Kumar \& Ghodeswar, 2015).

Eckhardt et al. (2010) found in their research that among the reasons that prevent consumers to conduct responsible consumption is economic rationality. Economic rationality concerns consumers that want to get the most value for their money, regardless of their ethical beliefs. The reasons for the limited "green" consumption were also reported in the studies of Carrington et al. (2014), Gleim et al. (2013) and Bray et al. (2011). These were mainly the unavailability of products, a narrow range, higher prices and lower quality of the environmental brands. Research of Picket-Baker \& Ozaki (2008) has demonstrated the problem of consumers to identify environmental products. Other significant barriers according to Carrigan \& Attalla (2001) are scepticism and lack of information (Hamzaoui-Essoussi \& Zahaf, 2009). Vokounova et al. (2013) confirm the biggest obstacles to sustainable consumption - a poor financial situation - worsened selection of economically weaker individuals, lack of information, lack of knowledge to process the information, or concerns about the availability and quality of products. To save our planet, to improve the current situation, it is necessary for the consumer to at least do the ecological minimum, i.e., separate waste, minimalize use of plastics, save water and energy and prefer green products when purchasing.

Consumers often consider the environmental aspect when purchasing products and services. A segment of consumers exists, that do not make their purchase decision primarily based on the price, but they take note of the ,green" image of the company. As stated by Chen (2010), green image of a company is mainly the perception of the brand in the mind of the consumer, while the brand is noticeably connected to the fulfilment of environmental commitments and environmental interests of the company. Companies react to the environmental behaviour and expectations of consumers with their green products and services (new or ecologically enhanced products), that bring environmental benefits. Green image can help a company attract more customers, and it can even evidently improve consumer loyalty to the company (Chang \& Fong, 2010). Gundova (2019) expresses that the green image of a company influences purchasing decisions, which increases the demand for green products. Bartok (2018), Mura \& Kljucnikov (2018) and Belas et al. (2019) confirm, that customers purchase not only the products but also the image of the company. A combination of appropriate factors can lead to purchase and the return of the customer as well (Pappas et al., 2017). A study provided by Karaosmanoglu et al. (2016) shows that consumers may be positively affected by CSR. Minarova (2014) suggest that a company has a moral obligation to serve society in a way that is environmentally friendly. 
The purchasing decision process and factors (including environmental factors), that influence consumer preferences, the purchase itself and the post-purchase evaluation of the product's usefulness are part of the consumer behaviour theory. Essentially, there are two groups of factors that affect the decisions to purchase environmental products. One group is natural for consumers, for example, it is their environmental responsibility, gaining knowledge and information, own interest, willingness to act in order to conserve natural resources, and limiting negative impact on the environment. The second group consists of factors related to the social image of consumers and the product characteristics (quality, safety, performance, price, impact on human health). The real behaviour is the result of regular consumer habits, their product knowledge and the impact of situational factors (e.g. communication campaign) (Kumar \& Ghodeswar, 2015).

Environmental awareness has multiple dimensional expression and is described in various ways in literature. Paul \& Rana (2012) declare five dimensions of understanding environmental awareness by Zsóka: environmental knowledge, environmental values, environmental attitudes, willingness to act and actual action. According their study, environmental awareness means the understanding of problems in/with environment. Motivation to the consumer action is closely related to understanding of these factors.

The level of consumer environmental awareness and their approach to environmental issues is also the starting point for market segmentation created by the Roper Organization and S.C. Johnson \& Sons. Consumers' approaches to the environment range from enthusiastic to complete indifference. In more developed countries, interest in environmental issues is naturally higher. As stated by Musová et al. (2018) the five segments of consumers based on their environmental attitudes were identified: True-blue greens are strongly involved in environment protection, Greenback greens are willing to pay more for environmentally friendly products. Sprouts are still "undecided" with a middling level of response. On the other side, Grousers use to rationalize their lack of pro-environmental behaviour and Basic Browns believe that individuals cannot make a difference in solving environmental problems. Members of individual segments also show different activity when purchasing environmental products.

Hasprova (2017) consider environmental awareness of consumers as a fundamental step in sustainable consumer behaviour. It is necessary for consumers to be aware of their influence on the environment, the impact of their consumption on the planet, society, but also their health and safety. Consumers increasingly prefer companies that act in a socially responsible manner and reject products of companies with an indifferent approach towards the environment and a negative environmental image. Environmental characteristics of a product are becoming a significant factor when choosing a product, in addition to price and quality. Environmental awareness and sustainable consumer behaviour are influenced by three groups of factors factors of environmental awareness (personal interest, perception, own responsibility, social pressure), factors of environmental consumption (perception of product's environmental aspects, knowledge of the environment, legal and economic incentives), and purchasing decision factors (consideration of price, quality, situational requirements, and barriers).

However, consumers usually lack the expertise to fully perceive the environmental quality of products. Thus, eco-labels could be an effective tool to disclose the environmental product quality. Fan et al. (2018) note that eco-labels inform consumers about the environmental impacts during the all phases of product life cycle (production, consumption, waste disposal) and allows consumers to differentiate between qualitatively similar products. Czarnezki et al. (2014) take the view that eco-labelling is one tool being increasingly used to deliver environmental information to consumers, however using this information is made difficult, as the number of alternative eco-labelling schemes has steadily increased. According to Ecolabel Index (2018) there are more than 464 eco-labels in existence. 
For example, more than a hundred eco-labels appeared on the German market over the last twenty years. However, the majority of Germans do not believe them. They have expressed that a large amount of the information provided is confusing, which generates distrust of the labels importance (Blue Angel, 2011).

Despite this, in Horne's (2009) view, eco-labels can affect consumer choice and play a significant role in their consumption decisions and in promoting sustainable consumption patterns too. Hence, eco-labelling is starting to show an impact on consumer's behaviour (Schumacher, 2010). Eco-labels influence consumer behaviour in two ways. First, they introduce green as a considered attribute at the point of sale. Second, they enable consumers to compare shop based on green.

Miklencicova (2015) in her research notes $79 \%$ of respondents (358 consumers in Slovakia) claimed that the labelling system of environmental products in Slovakia is insufficient. Merchants or sellers are of the opinion that the environmental awareness of consumers in Slovakia is low. More than a half, $65 \%$ of respondents do not know, or have never noticed environmental labelling on a product. Especially older consumers frequently do not understand graphic labels and do not take it into account when purchasing. The positive finding was, that about $75 \%$ of respondents were willing to learn more about environmental matters.

The similar study conducted in Poland (Witek, 2017) confirms that Polish consumers have positive attitudes towards eco-labels. Almost half of respondents buy eco-labelled products. Even $42 \%$ of research respondents believe that they have a high level of knowledge about eco-labelling. They perceive labels as an important way to communicate information about the different environmental characteristics of product.

In Hungary, primary research was carried out focused on the environmental awareness of students at Hungarian universities (Nagypál et al., 2015). Research has confirmed that students are environmentally conscious, have mature views and knowledge of sustainable consumption. However, the results of this study could be according authors characterized as "theoretical attitudes" in general. What was surprising about these results is, that knowledge about specific environmental labels was weak - brands and names of eco-labels were by students rather unknown. One of the reasons could be that consumers nowadays receive too much information about product and it is difficult to filter the relevant and true information. Secondly, in Hungary only a few eco-labelled products (especially ISO I type) are available, which also reduces popularity of eco-labels and consumers interest in this topic.

\section{Methodological approach}

The paper deals with the environmentally responsible behaviour of consumers in Slovakia. The main aim is to present the selected results of the primary research, which was focused on the most frequent responsible activities of consumers in the area of environmental protection in accordance with the principles of the circular economy. The environmentally responsible consumer behaviour in the context of selected demographic characteristics of consumers, approaches to environmental issues, and interest in environmental problems were also studied. It also includes research into consumer perception, knowledge and eco-labelling impact on purchasing behaviour.

In order to fulfil the main aim of the paper, the brief literature review have been carried out to create baseline for primary research planning. The data were collected in November and December 2018, mostly via online questionnaire survey. For senior respondents were questionnaires distributed in paper form. (Online questionnaire was available at: https://docs.google.com/forms/d/1VWZD5JfqxKgTIhjToNw2fahMenzjR7qXCWcgsrVets/edit). 
The questionnaire contained 15 questions in four sections. The first section was of a general nature and mainly focused on consumers' interest in environmental issues, displays of environmental responsibility and perception of environmental problems. The second section focused its attention on the implementation of environmentally responsible activities by consumers. The content of the third section was consumer purchasing behaviour with regard to the impact of various factors, including environmental factors. The last section consisted of identification data of respondents. The questionnaire included various types of questions mainly closed-ended questions (dual and multiple-choice response option) and Likert scale questions. In the following part only selected results are presented with regard to its content focus.

In total, 434 respondents participated in the questionnaire survey. The basic sample consisted of all active inhabitants of the Slovak Republic aged 18 to 62 years. In order to achieve research sample representativeness, we chose quota sampling in the terms of selected demographic criteria.

The sample representativeness according to gender and age by the Chi-square test was verified. The condition concerned to the expected frequencies was met. In both cases based on p-value (Asymp. Sig.) Table 1 and Table 2, the null hypothesis that the sample is representative was not rejected on the level of significance 0.05 .

Table 1. Test on Research Sample Representativeness (Gender)

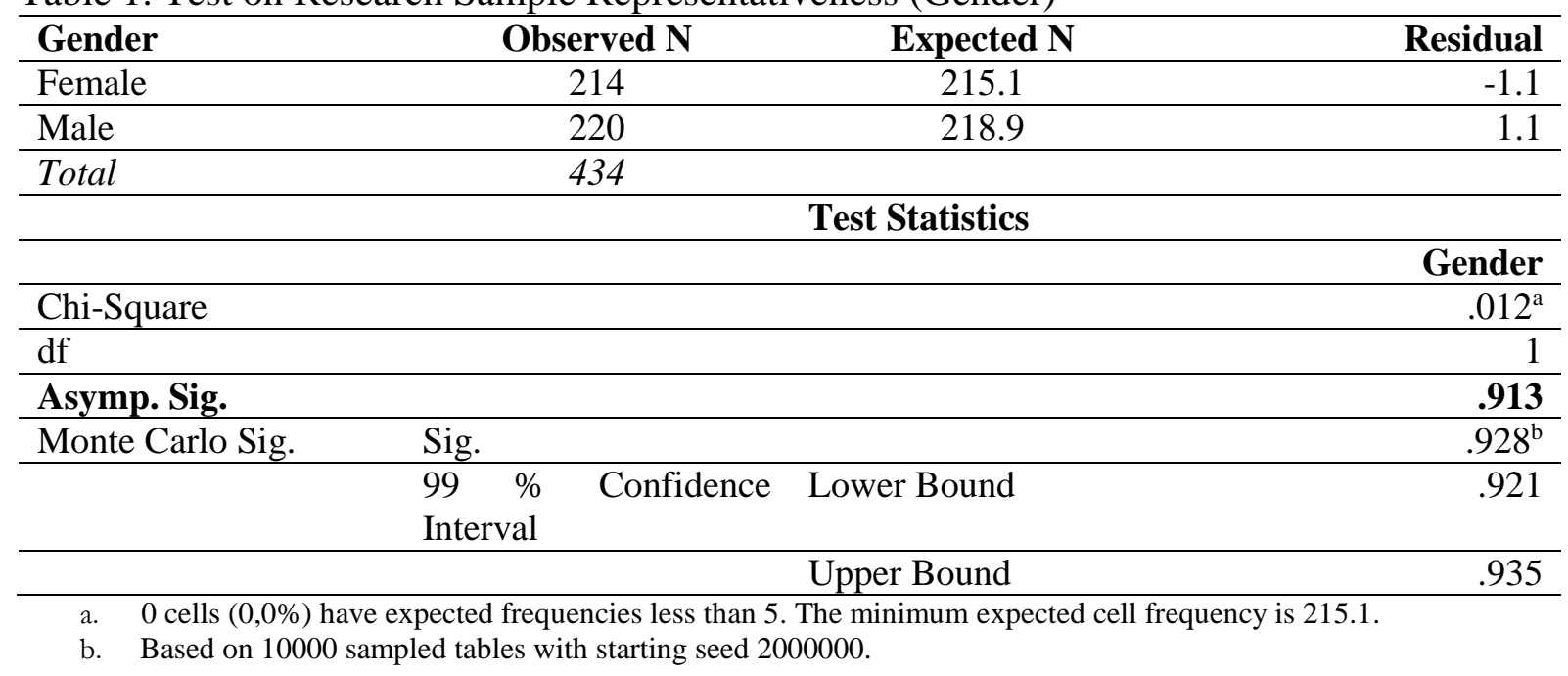

Source: own research and SPSS results

Table 2. Test on Research Sample Representativeness (Age)

\begin{tabular}{|c|c|c|c|}
\hline Age & Observed N & Expected N & Residual \\
\hline $18-26$ years & 76 & 76.4 & -.4 \\
\hline $27-46$ years & 202 & 203.4 & -1.4 \\
\hline $47-62$ years & 156 & 154.2 & 1.8 \\
\hline \multirow[t]{3}{*}{ Total } & 434 & & \\
\hline & & Test Statistics & \\
\hline & & & Age \\
\hline Chi-Square & & & $.033^{\mathrm{a}}$ \\
\hline $\mathrm{df}$ & & & 2 \\
\hline Asymp. Sig. & & & .984 \\
\hline \multirow[t]{3}{*}{ Monte Carlo Sig. } & Sig. & & $.987^{\mathrm{b}}$ \\
\hline & Confidence & Lower Bound & .984 \\
\hline & IIterval & Upper Bound & .980 \\
\hline
\end{tabular}


a. $\quad 0$ cells $(0,0 \%)$ have expected frequencies less than 5 . The minimum expected cell frequency is 76.4 .

b. Based on 10000 sampled tables with starting seed 299883525

Source: own research and SPSS results

There were $220(50.69 \%)$ men and $214(49.31 \%)$ women in the research sample. The least represented were respondents aged 18-26 (17.52\%), both men and women in approximately equal proportions. This group consisted mostly of students, young people looking for a job, or people who recently started their productive work periods. The majority of the respondents were between 27 and 46 years of age $(46.54 \%)$, the so-called "full nests" people starting a family, raising children and working people. The third group consisted of respondents from so-called "empty nests" (35.94\%).

Considering highest level of education achieved, almost $50 \%$ of respondents $(49.54 \%)$ had university education (bachelor's or master's degree), followed by respondents with high school education (38\%), and respondents with a secondary education but without GCE examination (almost 10\%). Regarding to number of household members, the most represented were households with four members $(40.1 \%)$, three-member households $(21.40 \%)$, followed by five and more members' households (18.20\%), households with two members $(17.50 \%)$, and the least represented were one-member households $(2.80 \%)$. Other identifying data were net monthly income of an individual (largest groups consisted of respondents with an income between 600 and 799 EUR (27.65\%), from 400 - 599 EUR (21.89\%) and from 800 - 999 EUR (17.97\%). Concerning to the place of residence, the most represented were residents from the Banska Bystrica region (33.64\%), Zilina region (23.5\%), and then the Presov region (20.28\%).

The survey data were analysed by descriptive methods and various statistical analysis tests. The representativeness of the sample according to the selected criteria was tested by the Chi-square test. Next we utilized the model of ordinal regression and factor analysis in order to research the connections of environmentally responsible consumer behaviour with their age, gender, environmental approaches, and implementation of environmental actions and knowledge of eco-labels.

In the first step, we defined environmentally responsible behaviour of consumers by the following facts and activities: *environmentally responsible behaviour is influenced by consumers' attitudes to environmental issues; *implementing environmentally responsible activities; *interest in the environment; *willingness to buy environmentally friendly products; *monitoring information provided by businesses on the environmental characteristics of the product (e.g. eco-labelling). Based on our "definition" of environmentally responsible behaviour of consumers, we estimated the relationship model of environmentally responsible behaviour and its relation to age, gender, household income and knowledge of eco-labelling using ordinal logistic regression. The output of ordinal logistic regression is supported by Hypothesis of significant improvement over the baseline intercept only model, Model fitting information, Test goodness of fit as well as Pseudo R square.

Before running the ordinal logistic regression, it is necessary to detect input variables by factor analysis. Through factor analysis we reduced the number of variables. Before undertaking the factor analysis, it is recommended to calculate sampling adequacy. Factor analysis requires the correlation of original input variables (Kral et al., 2009). It is possible to run the KMO criterion to assess the dependence of the input variables. The adequacy of a statistical sample can be determined when the resulting test value is greater than 0.6 (Kliestikova et al., 2019), but KMO value between 0.8 and 1 means the sampling is really adequate, concretely, if the value is in the spread 0.80 to 0.89 , adequacy is meritorious (Kaiser $\&$ Rice, 1974). The correlation matrix is an identity matrix, which would indicate that variables are unrelated, which is the null hypothesis of Bartlett's test of Sphericity (Durana et al., 2019). It is rejected the null hypothesis and it is accepted an alternative hypothesis; the correlation 
matrix is not an identity matrix based on a comparison of the significance level 0.05 and pvalue (Sig.) 0.000 in Table 3. The variables are related, and factor analysis is highly useful.

Table 3. Kaiser-Meyer-Olkin Test and Bartlett's Test

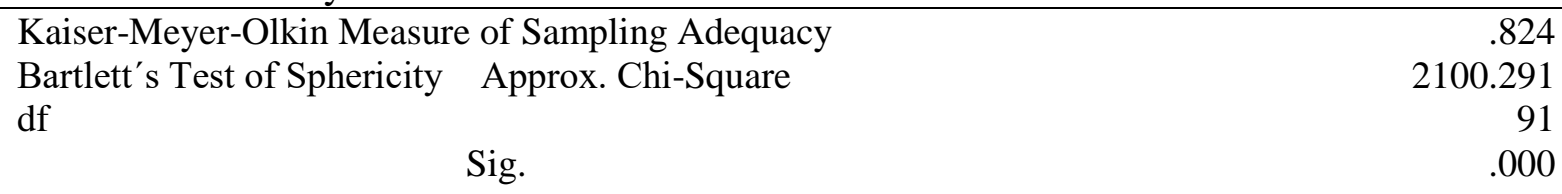

Source: own research and SPSS results

Assumption of correlation of eco-labels knowledge with gender, or the respondents' age were verified by the Chi-square tests and Spearman's correlation coefficient. The null hypotheses $\mathrm{H}_{0}$ and the alternative hypotheses $\mathrm{H}_{1 \mathrm{~A}}$ and $\mathrm{H}_{1 \mathrm{~B}}$ were tested at a significance level of 0,05 .

$H_{0}$ : No significant dependency exists between eco-labels knowledge and chosen variable.

$H_{1 A}$ : Significant dependency exists between eco-labels knowledge and gender.

$H_{1 B}$ : Significant dependency exists between eco-labels knowledge and the age.

As stated by Kascakova and Nedelova (2010) Pearson's Chi-square goodness of fit test is based on a frequency table and tests the statistical hypothesis that the frequencies in each category are equal to the expected (theoretical) frequencies.

\section{Empirical results and discussion}

Consumers' environmental behaviour in the opinion of Peattie (2010) includes such behaviour, that is concerned with the consumers' approaches to environmental products and their decision-making process takes into consideration the influence on the environment, regarding purchasing, use, and post-use behaviour (disposal, recycling, or re-use). Today, consumers are more informed, educated, and more demanding on how companies satisfy their needs. Segments of environmentally oriented consumers expect from companies' production processes that will not harm the environment, products that are environmentally friendly, for reasonable prices, distributed in such ways that have the least negative impact on the environment. Using recycled products, minimalizing waste, waste separation, conserving energy or reusing products are activities that correspond with the new economic model - the circular economy, which is currently discussed more and more by both professional and lay public.

We paid attention to the implementation of environmentally responsible activities of consumers. From the results we present the activities that correspond with the principles of circular economy.

Consumers pay an adequate amount of attention to waste minimization and separation. More than half of the consumers asked in the research separate waste always. More than a third of them answered that they separate waste sometimes, rather yes. As many as $75 \%$ of the respondents have stated that they conserve paper (they collect it in order to recycle it, or print only essential documents etc.). We have observed approximately the same results in energy and water conservation and the use of energy-efficient appliances. Consumers attribute less importance to transport-related activities (ecological driving, use of public transport). In terms of environmental purchasing behaviour, the situation is balanced when buying environmentally friendly products (positive vs negative answers), but the purchase of bio products and organic food lags behind significantly more. 
Table 4. Environmentally responsible activities - frequency

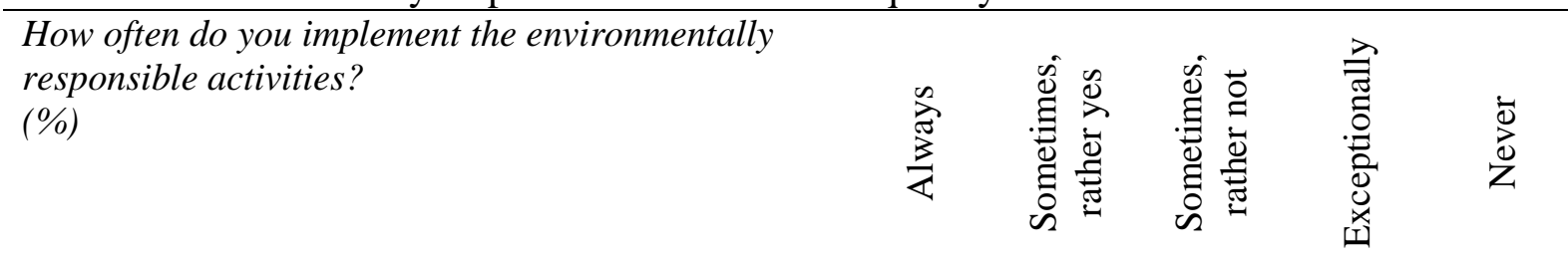

\begin{tabular}{|c|c|c|c|c|c|}
\hline \multicolumn{6}{|c|}{ RECYCLE } \\
\hline Waste separation & 51.84 & 35.71 & 9.46 & 2.30 & 0.69 \\
\hline \multicolumn{6}{|c|}{ REDUCE } \\
\hline $\begin{array}{l}\text { Paper conservation (collection for recycling, cutback } \\
\text { on printing) }\end{array}$ & $\mathbf{3 7 . 3 3}$ & 37.79 & 17.05 & 5.07 & 2.76 \\
\hline Energy conservation (electrical, gas...) & 41.94 & 43.55 & 11.75 & 1.61 & 1.15 \\
\hline Water conservation & 47.93 & 38.94 & 9.45 & 2.76 & 0.92 \\
\hline Use of energy-efficient appliances & 40.09 & 41.47 & 9.91 & 5.53 & 3.00 \\
\hline \multicolumn{6}{|c|}{ RETHINK - TRANSPORT } \\
\hline Ecological driving (electric cars, hybrids...) & 5.53 & 7.14 & 11.75 & 18.66 & 56.92 \\
\hline Use of public transport & 27.19 & 28.34 & 17.05 & 15.44 & 11.98 \\
\hline Use of bicycle transport & 17.05 & 22.35 & 22.58 & 18.20 & 19.82 \\
\hline Walking & 35.48 & 40.78 & 15.36 & 7.84 & 2.54 \\
\hline \multicolumn{6}{|c|}{ RETHINK - PURCHASING } \\
\hline I bring my own bag for shopping & 51.38 & 28.57 & 11.52 & 5.53 & 3.00 \\
\hline I purchase environmentally friendly products & 8.53 & 42.40 & 27.88 & 16.13 & 5.06 \\
\hline I purchase bio products and organic food & 7.60 & 33.87 & 30.88 & 16.82 & 10.83 \\
\hline I purchase products in recyclable packaging & 9.44 & 38.71 & 31.34 & 14.05 & 6.46 \\
\hline
\end{tabular}

Source: own research

The results of Eurobarometer "Attitudes of European citizens towards the environment" (EC, 2017) confirmed the most common environmental activity - the separation of waste for recycling in 23 of the 28 Member States. For example, 63\% of respondents in Portugal said they have done this in the last six months, while just $32 \%$ have done the next most common activity (reducing water consumption). Similar environmentally responsible behaviour was observed in other countries, such as Belgium, France, Italy, the Netherlands, Poland and Slovenia. Waste separating is at least $25 \%$ more often carried out compared with other environmental activities. In general, about two thirds $(65 \%)$ of Europeans say they have separated most of their waste for recycling, while the next reported activity was the purchase of local products (43\%). 35\% of respondents reduced their energy consumption.

Consumers are most motivated towards environmentally responsible behaviour by (1) internal belief (environmental responsibility is right) $-26.7 \%$ of respondents' answers, (2) they want to serve as an example for their children/surroundings $-24.6 \%$ (3) the belief that they contribute to the preservation of non-renewable resources $-18 \%$. A part of the consumers considers environmentally appropriate behaviour as a current trend and a part does not believe they can contribute to solving environmental problems through their behaviour (6.3\%).

The barriers and obstacles of environmentally responsible behaviour were also surveyed. Respondents were able to choose multiple responses (average of 2.85 responses). Respondents considered lack of money as the biggest barrier (e.g. purchase of more expensive environmentally friendly products, higher costs connected to environmentally responsible behaviour) $-22.8 \%$ of responses; lack of information ( $15.7 \%$ of responses); lack of time to carry out appropriate activities (e.g. separating, cleaning the environment, information gathering) $-15.4 \%$ and consumers' distrust towards cooperating organisations in protecting the environment $-14.7 \%$ of responses. 
Studies on consumers' environmental behaviour state that consumers who are aware of their individual consumption impact on the environment and deterioration of its, generally act environmentally more responsible and are interested in supporting of companies producing environmental-friendly products. Consumers are trying to help sustain their environment by demonstrating green purchasing behaviour (Dagher \& Itani, 2014). According to Steg \&Vlek (2009), a change in purchasing behaviour is generally more beneficial than reusing or recycling available products.

Based on examining theoretical background dealing with environmentally responsible behaviour, we defined environmentally responsible behaviour of consumers by a few facts and activities (for example attitudes to environmental issues, implementing environmentally responsible activities, interest in the environment, willingness to buy environmental products, monitoring information on the environmental product characteristics). The ordinal logistic regression was used to model the relationship between the environmentally responsible behaviour and socio-demographic characteristics (age, gender, household income) and ecolabel knowledge. Three new factors (from 14 original questions) were labelled as follows: Factor 1 - attitudes and approaches to environmental issues related to purchasing, seeking information about environmental problems, incentives towards environmentally responsible behaviour;

Factor 2 - carrying out the most significant environmental activities (saving water, saving energy and sorting waste);

Factor 3 - interest in environmental issues. New variables and results of the factor analysis shows Table 5. There is a rotated component matrix with all components made and all coefficients of used questions sorted by size and high factor saturations were marked.

Table 5. Factor Analysis Results

\begin{tabular}{|c|c|c|c|}
\hline \multirow{2}{*}{ Original variables } & \multicolumn{2}{|c|}{ New variables } & \multirow{2}{*}{$\frac{- \text { factors }}{3}$} \\
\hline & 1 & 2 & \\
\hline $\begin{array}{l}\text { I find it important that the products I purchase/use are as environmentally } \\
\text { friendlyas possible. }\end{array}$ & .750 & .262 & -.061 \\
\hline I search for information concerning environmental issues. & .741 & .035 & -.184 \\
\hline I am willing to pay extra for products that are environmentally friendly. & .729 & .160 & -.172 \\
\hline $\begin{array}{l}\text { If I find out that a product has a negative impact on the environment, I stop } \\
\text { buying. }\end{array}$ & .726 & .114 & -.106 \\
\hline $\begin{array}{l}\text { I motivate other family members and friends to be environmentally } \\
\text { responsible. }\end{array}$ & .639 & .227 & -.302 \\
\hline I am an active member of an environmental group/movement. & .582 & -.012 & .375 \\
\hline $\begin{array}{l}\text { I try to make my environmental behaviour contribute to preserving the } \\
\text { environment for future generations. }\end{array}$ & .558 & .272 & -.253 \\
\hline $\begin{array}{l}\text { I do not have enough time to be personally involved in solving environmer } \\
\text { problems, but I financially support an environmental organization or } \\
\text { solution to an environmental problem. }\end{array}$ & .507 & -.001 & 386 \\
\hline Water conservation & .069 & .839 & .028 \\
\hline Energy conservation (electrical energy, gas...) & .081 & .837 & .010 \\
\hline $\begin{array}{l}\text { Paper conservation (collection of old paper for recycling, printing of only } \\
\text { essential documents...) }\end{array}$ & .247 & .670 & -.146 \\
\hline Waste separation & .163 & .533 & -.329 \\
\hline I am not interested in environmental issues at all. & -.163 & -.151 & .793 \\
\hline $\begin{array}{l}\text { I see no importance in engaging in environmentally responsible activities. } \\
\text { Industrial and agricultural businesses are primarily responsible for } \\
\text { environmental pollution, so they should be addressed. }\end{array}$ & -.189 & -.048 & .773 \\
\hline
\end{tabular}

Source: own research and SPSS results 
Three factors were chosen based on principal component analysis as an extraction method and Varimax as a rotation method with Kaiser normalisation. Ideally, for interpreting any indicator should show saturation with just one factor. In practical situations, one indicator has high factor saturation with several factors. It is rotated and tried again repeatedly to ensure that each indicator has high saturation in one factor (Durana et al., 2019).

Originally correlated variables were replaced with new variables - factors that are linearly independent and are suitable as input variables for ordinal regression. Through the Goodness of Fit test, we have verified that our model is eligible to modelling the relationship between purchasing environmentally acceptable products, the first factor (attitudes to environmental issues), the second factor (implementation of environmental activities), the third factor (interest in the environment), age, gender, income and number of household members. Table 6 shows selected results of ordinal regression.

Table 6. Results of ordinal regression

\begin{tabular}{lrr}
\hline \multicolumn{1}{c}{ Observed items of environmentally responsible behaviour } & $\begin{array}{c}\text { Regression } \\
\text { coefficient }\end{array}$ & p-value \\
\hline F1 - attitudes to environmental issues & 1.363 & $\mathbf{. 0 0 0}$ \\
\hline F2 - carrying out environmental activities & 1.024 & $\mathbf{. 0 0 0}$ \\
\hline F3 - interest in environmental issues & -.408 & $\mathbf{. 0 0 0}$ \\
\hline Women & .367 & $\mathbf{. 0 8 0}$ \\
\hline Men & $0^{\mathrm{a}}$ &. \\
\hline $18-26$ years & -.580 & $\mathbf{. 0 9 0}$ \\
\hline $27-45$ years & -.415 & $\mathbf{. 0 6 1}$ \\
\hline 46-62 years & $0^{\mathrm{a}}$ &. \\
\hline Number of household members $=1$ & .169 & .781 \\
\hline Number of household members $=2$ & .653 & $\mathbf{. 0 4 6}$ \\
\hline Number of household members $=3$ & .491 & .115 \\
\hline Number of household members $=4$ & .382 & .156 \\
\hline Number of household members $=5$ & $0^{\mathrm{a}}$ &. \\
\hline Income $=0-199 €$ & -.569 & .231 \\
\hline Income $=200-399 €$ & -.934 & $\mathbf{. 0 3 0}$ \\
\hline Income $=400-599 €$ & -.119 & .713 \\
\hline Income $=600-799 €$ & -.116 & .705 \\
\hline Income $=800-999 €$ & -.305 & .356 \\
\hline Income $=1000+$ & $0^{\mathrm{a}}$ &. \\
\hline I am not interested in eco-labelling & -.049 & .938 \\
\hline I am not familiar with eco-labelling at all & -1.748 & $\mathbf{. 0 0 0}$ \\
\hline More likely not, I only know that some eco-labels exist & -.801 & $\mathbf{. 0 2 1}$ \\
\hline More likely yes, but I am unsure about their meaning & -.591 & $\mathbf{. 0 6 9}$ \\
\hline Certainly yes, I also know the meaning of eco-labels & $0^{\text {a }}$ &. \\
\hline Source: own research and $S P S S$ results & &
\end{tabular}

Source: own research and SPSS results

Based on p-value in Table 7 null hypothesis was rejected and it was accepted alternative hypothesis that the significant Chi-square statistic indicates that the model gives a significant improvement over the baseline intercept-only model. Table 8 contains Pearson's chi-square statistic for the model and another Chi-square statistic based on the deviance. If they are large, we may say that the model is appropriate. Cox and Snell and Nagelkerke Pseudo-R squared explains variance for $49.3 \%$ or $52.7 \%$. McFadden's Pseudo-R square in range 0.2-0.4 indicate extremely good fit (Table 9). 
Table 7. Model Fitting Information

\begin{tabular}{lrrrr}
\hline Model & \multicolumn{1}{c}{$\begin{array}{l}\text { Log } \\
\text { Likelihood }\end{array}$} & Chi-Square & df & \multicolumn{2}{c}{ Sig. } \\
\hline Intercept Only & 1192.003 & & & \\
Final & 997.928 & 294.075 & 19 & .000 \\
\hline
\end{tabular}

Link function: Logit.

Source: own research and SPSS results

Table 8. Test Goodnes-of-fit

\begin{tabular}{lrrr}
\hline & Chi-Square & df & \multicolumn{2}{r}{ Sig. } \\
\hline Pearson & 1666.071 & 1709 & .767 \\
Deviance & 897.928 & 1709 & 1.000 \\
\hline
\end{tabular}

Link function: Logit.

Source: own research and SPSS results

Table 9. Pseudo R Square

\begin{tabular}{ll}
\hline Cox and Snell & .493 \\
Nagelkerke & .527 \\
McFadden & .247 \\
\hline Link function: Logit.
\end{tabular}

Source: own research and SPSS results

Based on the results we conclude that statistically significant variables that influence environmentally responsible behaviour of consumers are age, gender, environmental attitudes, carrying out environmental activities, interest in the environmental issues, income, number of household members and knowledge of eco-labels. Under otherwise unchanged conditions, we can say that positive environmental attitudes and carrying out environmental activities increase the probability of environmentally responsible behaviour. On the contrary, lack of interest in the environment decreases this probability. Women are more likely to act environmentally responsible in comparison with men. Similar statements - that women are more environmentally responsible in comparison with men - are also confirmed by studies by Lee et al. (2013), Xiao \& Hong (2010), and Vinz (2009). Research of Smerichevskyi et al. (2018) emphasises that women are more active consumers of environmental goods and services and are leaders in decision making to buy such goods. It is mainly influenced by the fact that they purchase more and take care of the family health. In terms of the importance of eco-labels knowledge, consumers with a lack of eco-labelling knowledge behave less responsibly.

Environmentally responsible purchasing behaviour is considered to be one of the areas in which consumers are able to express their interest in environmental issues. Buying "green" products is one of the most popular ways to reduce the (negative) impact of an individual on the environment (Moser, 2016). Green purchasing also represents complex ethical decisionmaking behaviour and is considered to be a type of socially responsible behaviour. A socially responsible consumer takes into account the consequences of their consumption and tries to utilize their purchasing behaviour to bring about change (Rahman \& Joshi, 2016). Environmentally responsible purchasing is important because unplanned purchases of goods can cause harm to the environment. Grunert \& Juhl (1995) found in their studies that purchasing of consumers' households is responsible for $40 \%$ of the damage to the environment. Based on this we can establish that consumers are a major force and have the ability to prevent or reduce damage to the environment by purchasing "green" products (Rahman \& Joshi, 2016).

Barbarossa \& Pastore (2015) define environmentally responsible consumers as consumers who consider the environmental consequences of their private consumption or who 
attempt to use their consumption power to bring about environmental changes. With specific reference to the purchasing, Peattie and Crane (2005) are of the opinion that "green" consumers as those, who voluntarily purchase green products. They prefer environmentally friendly products and therefore they have a positive attitude towards companies that offer these products. Mala et al. (2017) acknowledge that while there is an increased interest in green products, the real demand for them is low.

In our research we found that among the three most influential factors in purchasing products were price ( $86.60 \%$ answers -376 respondents), quality $(82.30 \%$ answers -357 respondents) and previous experience with the product ( $57.40 \%$ answers -249 respondents). Unfortunately, environmental factors were less significant for the respondents. Consumers most often marked energy efficiency while utilizing the product (18\% answers -78 respondents) and recyclable packaging $(14.30 \%$ answers -62 respondents). Among the least impactful environmental factors were environmental characteristics of the product $(12.70 \%$ answers -55 respondents) and environmental image of the producer/retailer $(2.30 \%$ answers -10 respondents).

We were surprised to find that only a few consumers took into account the environmental image of the producers/retailers and environmental characteristics of the product when making their purchasing decision. We believe that these factors are not taken into account by consumers due to the lack of information, insufficient presentation and communication from the side of producers/retailers about environmental activities or more specifically about products with environmental characteristics. Consumers' lack of information is also confirmed by the Flash Eurobarometer 367 (EC, 2013). According to it, as many as $62 \%$ of respondents in Slovakia do not feel sufficiently informed about responsible activities from the side of businesses.

Across the EU, up to $80 \%$ of respondent at least sometimes buy environmentally friendly products - about a quarter of them do so regularly, more than half of them occasionally. Contrary to, $15 \%$ of EU citizens do not buy environmentally friendly products. The intention to buy such products in the future was expressed mainly by respondents in Bulgaria (11\%), Romania (8\%), the Czech Republic (7\%) and Slovakia (7\%). The citizen of Austria, Germany and Slovenia showed the smallest interest in the future (each $2 \%$ ). It can be assumed, that this is mostly due to the high prevalence of the maintenance behaviour stage in these countries. In fact, in these three countries the market for environmentally friendly products is more mature and most people are already buying them (EC, 2013).

In identifying the environmental attitudes of consumers, the respondents should comment on the following statement „I find it important that the products I purchase/use are as environmentally friendly as possible ". More than $16 \%$ of the respondents expressed a complete agreement, and almost $37 \%$ a partial agreement with the statement. $31 \%$ of the respondents had a neutral point of view. We confronted the positive approach with the real purchase of environmentally friendly products (we were verifying it while investigating environmental activities of consumers). To determine the dependence, we used the Spearman coefficient of correlation. We found a moderate correlation between the monitored variables $\left(r_{s}=0.524\right.$, $p$ value $=0.000)$. (Table 10). Based on the results we can state that respondents who expressed a positive approach to the importance of the purchase, or using environmentally friendly products, also actually buy them. 
Table 10. Environmental products purchasing - attitude vs real action

\begin{tabular}{|c|c|c|c|c|}
\hline & & & $\begin{array}{l}\text { I find it important, that } \\
\text { the products } \\
\text { I purchase/use are as } \\
\text { environmentally } \\
\text { friendly as possible. }\end{array}$ & $\begin{array}{l}\text { Purchase of } \\
\text { environmentally } \\
\text { friendly products }\end{array}$ \\
\hline \multirow[t]{6}{*}{$\begin{array}{l}\text { Spearman's } \\
\text { rho }\end{array}$} & \multirow{3}{*}{$\begin{array}{l}\text { I find it important, that } \\
\text { the products } \\
\text { I purchase/use are as } \\
\text { environmentally } \\
\text { friendly as possible }\end{array}$} & $\begin{array}{l}\text { Correlation } \\
\text { Coefficient }\end{array}$ & 1.000 & $.524^{* *}$ \\
\hline & & Sig. (2-tailed) & & 0.000 \\
\hline & & $\mathrm{N}$ & 434 & 434 \\
\hline & \multirow{3}{*}{$\begin{array}{l}\text { Purchase of } \\
\text { environmentally } \\
\text { friendly products }\end{array}$} & $\begin{array}{l}\text { Correlation } \\
\text { Coefficient }\end{array}$ & $.524^{* *}$ & 1.000 \\
\hline & & Sig. (2-tailed) & 0.000 & \\
\hline & & $\mathrm{N}$ & 434 & 434 \\
\hline
\end{tabular}

Source: own research and SPSS results

The next factor that can influence purchasing decision-making of consumers is ecolabelling, a universal concept, which is a part of strategies and policies of the environmental protection, sustainable development, and social responsibility. For Minarova et al. (2016), it is predominantly an optional tool of environmental management, focuses on the selected aspects of environmental product. The main aim of eco-labelling is to inform consumers and producers about the environmentally acceptable parameters of products, secondly to motivate them to use or produce such products. It is assumed, that eco-labelled products have better characteristics in terms of their impact on the environment in comparison with qualitatively comparable products (Musova, 2013).

Approximately only $13 \%$ of respondents know of eco-labels, including their meaning. $39 \%$ more likely know them, but they are not sure about their meaning. Less than half of the respondents has responded negatively in regard to knowledge of eco-labels (37\% only know, that some eco-labels exists; $7 \%$ have not observed any and $4 \%$ have absolutely interested in it. The structure of responds by gender and age shows Table 11.

In terms of eco-labels knowledge, respondents identified Slovak national eco-label „Environmentally friendly product “, eco-label of the EU (European flower), the label „Bio product”, German label „Blue Angel“ and the label „Not tested on animals“. Purchasing behaviour of respondents would be influenced (definitely, or most likely would influence) by the "Energy label” (40.09\%), the label „Not tested on animals“ (35.48\%) and the label „Bioproduct/product produced in ecological agriculture“ (28.11\%).

Table 11. Knowledge of eco-labels in \%

\begin{tabular}{|c|c|c|c|c|c|}
\hline \multirow[b]{2}{*}{ Knowledge of eco-labelling } & \multicolumn{3}{|c|}{ Age } & \multicolumn{2}{|c|}{ Gender } \\
\hline & $\begin{array}{l}18-26 \\
\text { years }\end{array}$ & $\begin{array}{l}27-45 \\
\text { years }\end{array}$ & $\begin{array}{l}46-62 \\
\text { years }\end{array}$ & Women & Men \\
\hline Certainly yes, I also know their meaning & 3.23 & 6.91 & 3.00 & 7.83 & 5.30 \\
\hline $\begin{array}{l}\text { More likely yes, but I am unsure what it } \\
\text { means }\end{array}$ & 10.60 & 17.51 & 10.83 & 20.51 & 18.43 \\
\hline $\begin{array}{l}\text { More likely not (I only know that some } \\
\text { eco-labels exist) }\end{array}$ & 3.22 & 15.90 & 17.74 & 17.97 & 18.89 \\
\hline Not at all, I have not observed any & 0.23 & 3.69 & 3.46 & 2.53 & 4.84 \\
\hline I have absolutely no interest in it & 0.23 & 2.53 & 0.92 & 0.46 & 3.23 \\
\hline
\end{tabular}

Source: own research 
We were interested in whether the knowledge of eco-labels is related to the gender and age of our respondents (hypothesis $\mathrm{H}_{0}, \mathrm{H}_{1 \mathrm{~A}}, \mathrm{H}_{1 \mathrm{~B}}$ ). We verified this relationship by a Chi-square test. Based on the results $(\chi 2=39.780$; p-value 0.000$)$, we accept our assumption about this relation. Using cross tables, we compared individual answers between age categories. The results show that respondents aged 27 - 45 have the best knowledge of eco-labelling, including its meaning. Similarly, we also verified the assumption that there is a relationship knowledge of eco-labelling and the gender of the consumer $(\chi 2=15.009 ; p$-value 0.005$)$. In terms of gender, women have better knowledge of eco-labels (Tables 12).

Table 12. Chi-square tests - Knowledge of eco-labels and gender/age

\begin{tabular}{|c|c|c|c|c|c|c|}
\hline \multicolumn{7}{|c|}{ Statistical testing } \\
\hline & \multicolumn{3}{|c|}{ GENDER } & \multicolumn{3}{|c|}{ AGE } \\
\hline & Value & & $\begin{array}{l}\text { mp. } \\
\text { (2- } \\
\text { ed) }\end{array}$ & Value & & $\begin{array}{l}\text { mp. } \\
\text { (2- } \\
\text { ed) }\end{array}$ \\
\hline Pearson Chi-Square & $15.009^{\mathrm{a}}$ & 4 & .005 & $39.780^{\mathrm{a}}$ & 8 & .000 \\
\hline Likelihood Ratio & 16.201 & 4 & .003 & 42.003 & 8 & .000 \\
\hline $\begin{array}{l}\text { Linear-by-Linear } \\
\text { Association }\end{array}$ & 12.372 & 1 & .000 & 19.640 & 1 & .000 \\
\hline $\mathrm{N}$ of Valid Cases & 434 & & & 434 & & \\
\hline & $\begin{array}{l}\text { a. } 0 \text { cells }(0.0 \%) \\
\text { 5. The minimum }\end{array}$ & & s than & $\begin{array}{l}\text { a. } 1 \text { cells }(6.7 \% \\
\text { than } 5 . \text { The min }\end{array}$ & ta & $\begin{array}{l}s .80 . \\
\text { ss } \\
2.80 .\end{array}$ \\
\hline
\end{tabular}

Source: own research and SPSS results

Our investigation related to the differences in gender are in line with studies of Liobikiene et al. (2017) and Hojnik et al. (2019), which found that woman behave in a more environmentally friendly way and are more consciousness of eco-labelled products than male consumers. Green purchase behaviour is significantly related to environmentally friendly behaviour. Study of Chekima et al. (2016) confirmed that environmental attitude and eco-label significantly influence green purchase intention as well. The findings revealed that gender (and education level) have positive moderation effect. This suggests that motivational factors for green purchase are greater among highly educated individuals, especially with female consumers.

In Special Eurobarometer 468 (EC, 2017) more than a quarter of respondent's claim having heard of the EU eco-label. Still there is a considerable variation in levels of awareness of the EU eco-label among EU member states. In three countries, at least half of respondents has seen or heard about the EU ecolabel: Luxembourg (62\%), France (61\%) and Denmark (51\%). However, in Romania (13\%), Bulgaria (14\%), the Czech Republic (16\%), the UK and Italy (both $17 \%$ ) as well as in Slovakia (20\%) is the recognition of the EU eco-label the lowest. Generally, around third of respondents declare ecolabels play an important role in their purchasing decision. On the other hand, it is not major aspect while purchasing within a quarter of respondents. Furthermore, another 39\% expressed they never notice such labels when choosing products.

\section{Conclusion}

Actions of several consumers towards environment are strongly responsible and their environmental awareness grows. An increasing number of consumers tend to purchase and consume environmentally-friendly products with the aim to protect and preserve the environment for future generations. 
We have focused on finding out various aspects of environmentally responsible behaviour of consumers in Slovakia in our primary research as well. In the first part we paid attention on the implementation of selected environmentally responsible activities of consumers carried out in the context of principles of the circular economy. We have recorded the best results in waste separation (under the recycling principle), consumers act responsibly in activities related to reducing consumption (energy, water, using energy-saving appliances). Other activities also confirm positive changes in consumers' perception and approaches to environmental issues (rethink), although they are less pronounced (purchasing environmentally friendly products, bio products and organic food). Statistical testing confirmed the moderate correlation between positive attitudes to purchasing environmentally friendly products and real purchases of consumers.

Based on the results of factor analysis and ordinal logistic regression, we conclude that positive environmental attitudes and conducting environmental activities increase the probability of environmentally responsible behaviour. On the contrary, lack of interest in the environment decrease this probability. Statistically significant variables that influence environmentally responsible consumer behaviour include age, gender, and income, number of household members and knowledge of eco-labels.

It is precisely the knowledge of eco-labels that can be a significant factor impacting environmentally responsible purchasing behaviour of consumers. Only average knowledge of eco-labels resulted from the research under Slovak conditions, while the impact on purchasing decision-making was confirmed and significant only in the case of selected eco-labels. The best knowledge was found in respondents from so-called "full nests" (27-45 years). Based on gender, women have better knowledge in comparison with men.

The research outcomes will be useful as a recourse for further, more detailed examination into environmentally responsible behaviour of the market player in the circular economy implementation. Researched issue is topical, dynamically developing and will evoke intensive discussion about possibilities to improve quality of life and environment and sustainability for future generations.

\section{Acknowledgement}

The authors are thankful to the Scientific Grant Agency of Slovak Republic under project VEGA No.1/0705/19 "The responsibility of selected market entities as a significant determinant for application of circular economy principles in Slovakia".

\section{References}

ANON. (2015). Eco-labels Impact Consumer Behavior. Retrieved May 15, 2020,fromhttps://marketinggreen.wordpress.com/2008/05/24/eco-labelsimpactconsumer-behavior/

Barbarossa, C., \& Pastore, A. (2015). Why environmentally conscious consumers do not purchase green products. A cognitive mapping approach. Qualitative Market Research, 18(2), 88-209. doi:10.1108/QMR-06-2012-0030

Bartok, O. (2018). The Use of CSR in E-Commerce as a Way to Compete. Journal of Competitiveness, 10(4), 5-20. doi: org/10.7441.joc.2018.04.01

Belas, J., Strnad, Z., Gavurova, B., \& Cepel, M. (2019). Business environment quality factors research - SME management's platform. Polish Journal of Management Studies, 20(1), 64-77. doi: 10.17512/pjm.2019.20.1.06. 
Blue Angel. (2011). The blue angel - what's behind it? Growing information needs of consumers. Retrieved May 15, 2020, from http://www.blauerengel.de/en/blauer_engel/whats_behind_it/index.php

Braam, G., Ewen, D., Ossenblok, L., Toxopeus, H., \& Maas, K. (2018). Circular Route. A Roadmap for Circular Business Model. Delft, Eburon.

Bray. K., Johns, N., \& Kilburn, D. (2011). An exploratory study into the factors impeding ethical consumption. Journal of Business Ethics, 98(4), 597-608

Carrigan M., \& Attalla, A. (2001). The myth of the ethical consumer: does ethics matter in purchase behaviour? Journal of Business Ethics, 18(7), 560-577

Carrington, M. J., Neville, B. A., \& Whitwell, G. J. (2014). Lost in translation: exploring the ethical consumer intention - behaviour gap. Journal of Business Research, 67(1), 27592767

Chiou, T., Chan, H., Lettice, F., \& Chung, S. (2011). The influence of greening the suppliers and green innovation on environmental performance and competitive advantage in Taiwan. Transportation Research Part E, 47(6), 822-836

Czarnezki, J. J., Pollans, M. J., \& Main, S. (2018). Eco-Labeling. http://dx.doi.org/10.2139/ssrn.3230440

Dagher, K., \& Itani, O. (2014). Factors influencing green purchasing behaviour Empirical evidence from the Lebanese consumers. Journal of Consumer Behaviour, 13(3), 188

Dagher, G. K., Itani, O., \& Kassar, A. N., (2015). The Impact of Environment Concern and Attitude on Green Purchasing Behavior: Gender as the moderator. Contemporary Management Research, 11(2), 179-206, doi:10.7903/cmr.13625

Dunlap, R. \& Jones, R. (2002). Environmental Concern: Conceptual and Measurement Issues. In Dunlap and Michelson (Ed), Handbook of Environmental Sociology, 482-542. London, Greenwood Press.

Durana, P., Kral, P., Stehel, V., Lazaroiu, G., \& Sroka, W. (2019). Quality Culture of Manufacturing Enterprises: A possible way to adaptation to Industry 4.0. Social Sciences, 8(4), 124.

Ertz, M., Francois, J., \& Durif, F. (2017). How consumer react to environmental information: An experimental study. Journal of International Consumer Marketing, 3(29), 162-178. doi: 10.1080/08961530.2016.1273813

Esmaeilpour, M., \& Bahmiary, E (2017). Investigating the impact of environmental attitude on the decision to purchase a green product with the mediating role of environmental concern and care for green products. Management \& Marketing Challenges for the Knowledge Society, 12(2), 297-315. doi: 10.1515/mmcks-2017-0018

European Commission. (2013). Flash Eurobarometer 367. Attitudes of Europeans towards building the single market for green products. Retrieved May 25, 2020, from http://ec.europa.eu/public_opinion/flash/fl_367_en.pdf

European Commission (2014). Special Eurobarometer 416. Attitudes of European citizens towards the environment. Retrieved May 25, 2020 from http://ec.europa.eu/public_opinion/archives/ebs/ebs_416_en.pdf

European Commission. (2017). Special Eurobarometer 468. Attitudes of European citizens towards the environment. Retrieved May 25, 2020, from https://data.europa.eu/euodp/en/data/dataset/S2156_88_1_468_ENG

Fan, T., Song, Y, Cao, H., \& Xia, H. (2019). Optimal eco-labeling strategy with imperfectly informed consumers. Industrial Management \& Data Systems, 119(6), 11661188. https://doi.org/10.1108/IMDS-06-2018-0256 
Finisterra do Paco, A. M., Raposo, M., \& Filho, W. L. (2009). Identifying the green consumer: a segmentation study. Journal of Targeting, Measurement \& Analysis for Marketing, $17(1), 17-25$

Fraj, E., \& Martinez, E. (2007). Ecological consumer behaviour: an empirical analysis. International Journal of Consumer Studies, 31(1), 26-33

Gadenne, D., Sharma, B., Kerr, D., \& Smith, T. (2011). The influence of consumers' environmental beliefs and attitudes on energy saving behaviour. Energy Policy, 39, 76847694. doi: 10.1016/j.enpol.2011.09.002

Gleim, M., Smith, J. S., Andrews, D., \& Cronin, J. (2013). Against the green: A multi-method examination of the barriers to green consumption. Journal of Retailing, 89(1), 44-61

Gundova, P. (2019). Zelene produkty a sluzby prinasajuce environmentalne benefity. In Lesakova, L. (Ed.) Vybrane otazky skumania eko-inovacii. Banska Bystrica, Belianum

Hamzaoui-Essoussi, L., \& Zahaf, M (2009). Exploring the decision-making process of Canadian organic food consumers: motivation and trust issues. Qualitative Market Research: An International Journal, 12(4), 443-459

Hankammer, S., Brenk, S., Fabry, H., Nordemann, A., \& Piller, F. T. (2019). Towards circular business models: Identifying consumer needs based on the jobs to be done theory. Journal of Cleane rProduction, 231, 341-356.

Hasprova, M. (2017). Marketing a spolocnost. In Kita et al. Marketing. Bratislava, Wolters Kluwer, 44-62

Hojnik, J., Ruzzier, M.,\& Ruzzier, M. K., (2019). Transition towards Sustainability: Adoption of Eco-Products among Consumers. Sustainability, 11, 4308, 1-29. doi: $10.3390 / \mathrm{su} 11164308$

Horne, R. E. (2009). Limits to labels: The role of eco-labels in the assessment of product sustainability and routes to sustainable consumption. International Journal of Consumer Studies, 33, 175-182. doi:10.1111/ijc.2009.33.issue-2

Howard-Grenville, J., Buckle, S. J., Hoskins, B. J., \&George, G. (2014). Climate change and management. Academy of Management Journal, 57(3), 615-623. doi: 10.5465/amj.2014.4003

Chekima, B., Wafa, S. A., Igau, O. A., \& Chekima, S. (2016). Examining green consumerism motivational drivers: Does premium price and demographics matter to green purchasing? Journal of Cleaner Production. 112, 3436-3450.

Juwaheer, T., Pudaruth, S., \& Noyaux, M. (2012). Analysis the impact of green marketing strategies on consumer purchasing patterns in Mauritius. World Journal of Entrepreneurship, Management and Sustainable Development, 8(1), 36-59.

Kaiser, Henry F., \& John Rice. (1974). Little Jiffy Mark IV. Educational and Psychological Measurement 34, 111-117.

Karaosmanoglu, E., Altinigne, N., \& Isiksal, D. G. (2016). CSR motivation and customer extrarole behavior: Moderation of ethical corporate identity. Journal of Business Research, 69(10), 4161-4167.

Kilbourne, W., \& Pickett, G. (2008). How materialism affects environmental beliefs, concern, and environmentally responsible behaviour. Journal of Business Research, 61, 885-893.

Kliestikova, J., Durana, P., \& Kovacova, M. (2019). Naked consumer's mind under branded dress: Case Study of Slovak Republic. Central European Business Review, 8(1), 15-32.

Kral, P., Kanderova, M., Kascakova, A., Nedelova, G., \& Valencakova, V. (2009). Viacrozmerne statisticke metody so zameranim na riesenie problemov ekonomickej praxe. Banska Bystrica, Univerzita Mateja Bela.

Kumar, P., \& Ghodeswar, B. (2015). Factors affecting consumers' green product purchase decisions. Marketing Intelligence \& Planning, 33(3), 330-347 
Lee, E., Park, N. K., \& Han, J. H. (2013). Gender difference in environmental attitude and behaviors in adoption of energy-efficient lighting at home. Journal of Sustainable Development, 6(9), 36-50.

Liobikienè, G., Grincevičienè, Š., \& Bernatonienė, J. (2017). Environmentally friendly behaviour and green purchase in Austria and Lithuania. Journal of Cleaner Production, 142, 3789-3797. doi.org/10.1016/j.jclepro.2016.10.084

Mala, D., Sedliacikova, M., \& Bencikova, D. (2018). How customers of small and medium wood-processing Slovak enterprises perceive a green product. Bioresources, 13(1), 19301950.

Miklencicova, R. 2015. Perception of environmental product labelling by Slovak consumers. In Procedia Economics and Finance, 34, 644-648.

Minarova, M. (2014). Emocionalna inteligencia ako súcast kompetentnosti manazera/Emotional Intelligence as Part of the Manager's Competence. Banska Bystrica, Vydavatel'stvo Belianum.

Minarova, M., Musova, Z., \& Bencikova, D. (2016). Eco-labels and consumers. Marketing Identity 2016. Brands we love. Trnava, University od Ss. Cyril and Methodius.

Mostafa, M. M. (2007). Gender differences in Egyptian consumers' green purchase behaviour: the effects of environmental knowledge, concern and attitude. International Journal of Consumer Studies, 31(3), 220-229.

Moser, A. K. (2016). Consumers' purchasing decisions regarding environmentally friendly products: An empirical analysis of German consumers. Journal of Retailing and Consumer Services, 31, 389-397.

Mura, L., \& Kljucnikov, A. (2018). Small Businesses in rural tourism and agrotourism: Study from Slovakia. Economics \& Sociology, 11(3), 286-300. doi: 10.14254/2071789X.2018/11-3/17.

Musova, Z., (2013). Spolocenska zodpovednost v marketingovej praxi podnikov. Banska Bystrica, Univerzita Mateja Bela, Ekonomicka fakulta.

Musova, Z., Musa, H., \& Ludhova, L. (2018). Environmentally responsible purchasing in Slovakia. Economics \& Sociology, 11(4), 289-305. http://dx.doi/10.14254/2071789X.2018/11-4/19.

Nagypál, N. C., Görög, G., Harazin, P., \& Baranyi, R. P. (2015). „Future generations“ and sustainable consumption. Economics \& Sociology, 8(4), 207-224. doi: 10.14254/2071789X.2015/8-4/15.

Newton, J., Tsarenko, Y., Ferraro, C., \& Sands, S. (2015). Environmental concern and environmental purchase intentions: The mediating role of learning strategy. Journal of Business Research, 68(9), 1974-1981.

Onel, N., \& Mukherjee, A. (2016). Consumer knowledge in pro-environmental behaviour: An exploration of its antecedents and consequences. World Journal of Science, Technology and Sustainable Development, 13(4), 328-352.

Pajtinkova Bartakova, G., \& Gubiniova, K. (2012). Udrzatelny marketingovy manazment. Trencin, IAM.

Pappas, I. O., Kourouthanassis, P. E., Giannakos, M. N., \& Lekakos, G. (2017). The interplay of online shopping motivations and experiential factors on personalized ecommerce: A complexity theory approach. Telematics and Informatics, 34 (5), 730-742. https://dx.doi/10.1016/j.tele.2016.08.021.

Paul, J., \& Rana, J. (2012). Consumer behaviour and purchase intention for organic food. Journal of Consumer Marketing, 29(6), 412-422. doi: 10.1108/07363761211259223.

Peattie, K., \& Crane, A. (2005). Green marketing: legend, myth, farce or prophesy?. Qualitative Market Research, 8(4), 357-370. 
Peattie, K. (2010). Green consumption: behavior and norms. Annual Review of Environment and Resources, 35, 195-228.

Pham, N. T., Tuckova, Z., \& Phan, Q. P. T. (2019). Greening human resource management and employee commitment toward the environment: An interaction model. Journal of Business Economics and Management, 20(3), 446-465. doi: 10.3846/jbem.2019.9659

Pickett-Baker, J., \& Ozaki, R. (2008). Pro-environmental products: Marketing influence on consumer purchase decision. Journal of Consumer Marketing, 25(5), 281-293.

Potocan, V., Nedelko, Z., Peleckienè, V., \& Peleckis, K. (2016). Values, environmental concern and economic concern as predictors of enterprise environmental responsiveness. Journal of Business Economics and Management, 17(5), 685-700. doi:10.3846/16111699.2016.1202315

Rahman, Z., \& Joshi, Y. (2016). Predict purchase behaviour. Management of Environmental Quality: An International Journal, 27.

Roman, T., Bostan, I., Manolica, A., \& Mitrica, I. (2015). Profile of Green Consumers in Romania in Light of Sustainability Challenges and Opportunities. Sustainability, 7.63946411. doi: 10.3390/su7066394

Smerichevskyi, S., Kniazieva, T., Kolbushkin, Y., Reshetnikova, I., \& Olejniczuk-Merta, A. (2018). Environmental orientation of consumer behaviour: Motivational component. Problems and Perspectives in Management, 16(2), 424-437.

Schumacher, I., (2010). Ecolabeling, consumers' preferences and taxation. Ecological Economics, 69. 2202-2212.

Steg, L., \& Vlek, C. (2009). Encouraging pro-environmental behaviour: an integrative review and research agenda. Journal of Environmental Psychology, 29(3), 309-317.

Vinz, D. (2009). Gender and sustainable consumption: A German environmental perspective. European Journal of Women's Studies, 16(2), 159-179.doi: 10.1177/1350506808101764

Vokounova, D., Korcokova, M., \& Hasprova, M. (2013). Udrzatelny rozvoj a udrzatelna spotreba (vybrane problemy). Bratislava, Vydavatelstvo Ekonom.

Witek, L. (2017). Sustainable Consumption: Eco-labelling and its impact on consumer behavior - evidence from a study on Polish consumer. 9thInternational Conference on Applied Economics Contemporary Issues in Economy, Torun, 22-23 June 2017

Xiao, C., \& Hong, D. (2010). Gender differences in environmental behavior in China. Population and Environment, 32, 88-104. doi: 10.1007/s11111-010-0115-z. 